DOI: $10.15593 / 2224-9354 / 2020.4 .16$

УДК 005.334.4:347.447.84

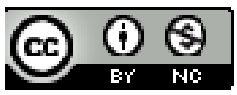

\title{
Г.Е. Концевич
}

\section{УРЕГУЛИРОВАНИЕ УБЫТКОВ ЧЕРЕЗ ЕВРОПРОТОКОЛ}

Одним из самых распространенных видов страхования является автострахование. Это связано с тем, что с каждым днем стремительно увеличивается количество автомобилей на дорогах, в связи с чем появляется больше шансов попасть в дорожно-транспортное происшествие (ДТП).

В Российской Федерации существует 2 вида автострахования: добровольное («Автокаско») и обязательное страхование автогражданской ответственности (ОСАГО). Согласно законодательству, каждый владелец транспортного средства должен иметь полис ОСАГО.

Урегулирование убытков по ОСАГО может происходить как с участием сотрудников ГИБДД, так и без них через европротокол. В страховой компании «СОГАЗ» чаще всего убытки регулируются посредством европротокола. На сегодняшний день все незначительные аварии оформляются только через извещение о дорожно-транспортном происшествии, но не все страхователи имеют полное представление о европротоколе и нередко делают ошибки.

Европейский протокол давно используется в большинстве стран мира, что делает его удобным при путешествии на автомобиле за границу (при условии, что имеется «Зеленая карта»).

Цель исследования данной работы - изучить сущность извещения о дорожно-транспортном происшествии (европейского протокола) и урегулирование убытков по ДТП посредством этого протокола.

Европротокол - очень полезная вещь по своей задумке. Но недостаточная степень его нормативной проработки, к сожалению, не позволяет популяризировать схему. Кроме того, практика его применения вносит свои коррективы. В связи с этим самостоятельное оформление дорожнотранспортного происшествия во многом связано с определенными рисками. Сложность системы и недостаточная осведомленность об этом инструменте становится причиной многих ошибок, которые совершают страхователи, оформляя дорожно-транспортное происшествие. Из-за этих ошибок могут возникнуть проблемы с выплатой страхового возмещения по полису обязательного страхования автогражданской ответственности.

В то же время доля отказов в возмещении ущерба по европротоколу из-за ошибок в оформлении колеблется в пределах 1-5 \% от общего числа обращений. А значит, в подавляющем большинстве случаев участники ДТП вполне справляются с задачей.

Система европейского протокола в России продолжает совершенствоваться, и можно быть уверенным в том, что в будущем именно благодаря ей процесс урегулирования убытков станет еще проще и быстрей.

Ключевые слова: убытки, европротокол, страхование, участники, возмещение, автомобиль, происиествие, автострахование, ответственность, рыночные отношения.

Страхование автотранспортных средств необходимо для защиты интересов страхователей (выгодоприобретателей) при наступлении страхового случая. Для покрытия ущерба страховые компании формируют денежные средства из уплаченных страхователями страховых премий (взносов), а также из иных источников. Выгодоприобретатель, согласно договору страхования, может являться как страхователем, так и другим лицом.

(C) Концевич Г.Е., 2020

Концевич Галина Евгеньевна - канд. социол. наук, доцент кафедры гуманитарных и социально-экономических дисциплин Филиала ГБОУ ВО «Ставропольский государственный педагогический институт» в г. Железноводске, e-mail: galinakoncevich@rambler.ru. 
Страхование может быть добровольным или обязательным, личным (страхование жизни и здоровья) или имущественным.

Для осуществления своей деятельности страховщик обязан иметь лицензию.

В Российской Федерации закон обязывает владельцев транспортных средств страховать только свою ответственность (ОСАГО). Остальные виды автострахования являются добровольными. Владельцы автотранспортных средств могут воспользоваться следующими видами страхования:

- полное страхование (от всех рисков);

- страхование от несчастных случаев;

- «Автокаско»;

- страхование грузов при перевозках [1, с. 12].

Страхование от всех рисков - это самый дорогой вид автострахования. После наступления страхового случая страховая компания возместит все убытки, которые были связаны с гибелью или повреждением автомобиля, причинением вреда жизни или здоровью людей, повреждением имущества третьих лиц, причинением ущерба багажу, находящемуся в транспортном средстве на момент аварии.

Водитель и пассажиры могут быть застрахованы от несчастного случая при ДТП, повлекшим за собой серьезные травмы, ранения или увечья, временную или постоянную утрату трудоспособности, смерти застрахованного лица. Существует два вида страхования от несчастного случая:

1. «Система мест». Согласно данной системе, страховая сумма устанавливается для каждого места в транспортном средстве (ТС). Общее число застрахованных устанавливается по данным техпаспорта ТС.

2. «Паушальная система». Устанавливается общая страховая сумма на всех лиц, находящихся в автомобиле, и каждый из них считается застрахованным лицом в определенной доле от нее. Размер доли зависит от количества пассажиров, находящихся в автомобиле.

Страхование «Автокаско» возмещает ущерб, связанный с полной гибелью, повреждением, утратой транспортного средства или его отдельных частей. Все страховые случаи «Автокаско» должны быть прописаны в страховом полисе. По «Автокаско» можно застраховать только автомобиль и его части. Пассажиры, грузы и ответственность не страхуются. «Автокаско» может быть полным и частичным [2, с. 12].

При полном страховании «Автокаско» возмещаются убытки, связанные:

- с дорожно-транспортным происшествием;

- столкновением автомобиля с другим предметом (стена, забор, фонарный столб и т.д.);

- опрокидыванием ТС;

- пожара, взрыва;

- стихийного бедствия (град, землетрясение и др.); 
- противоправными действиями третьих лиц (кража авто, кража колес, разбивание стекол, фар и т.д.).

Но кроме ущерба, имеющего эксплуатационный характер.

При частичном страховании «Автокаско» покрывает ущерб, возникший вследствие:

- пожара или взрыва, случившегося из-за внешних воздействий;

- повреждения авто упавшим или отскочившим предметом;

- стихии (град, буря, ураган, землетрясение, наводнение);

- противоправных действий третьих лиц в отношении автомобиля;

- кража ТC.

Страхование «Автокаско» не покрывает убытки:

- возникшие при эксплуатации автомобиля;

- связанные с вождением автомобиля в состоянии алкогольного или наркотического опьянения;

- возникшие во время обучения вождению или участия в гоночных соревнованиях и испытаниях;

- от естественного износа транспортного средства, отдельных его частей и деталей;

- связанные с повреждением автомобиля при ДТП, которое было организованно мошенническим путем.

Страхование грузов при перевозках необходимо, когда страхователь использует автомобиль для перевозок как предприниматель [3, с. 18].

В России страхование «Каско» не так распространено, как ОСАГО. Это связано с высокой стоимостью полисов «Каско» и уверенностью водителей в том, что с их транспортным средством ничего не случится. ОСАГО возникло в США, в связи с этим рассмотрим действие данного вида страхования за рубежом.

Автострахование и проблемы, связанные с ним за рубежом, не являются новинкой на страховом рынке. Со времен появления этого вида страхования развитые страны пытаются решать проблемы, возникающие при страховании автомобилей $[4$, с. 8].

Страхование гражданской ответственности владельцев транспортных средств стремительно развивается с начала XXI в. Именно в этот период происходит бурное развитие автомобильного движения, а вместе с ним все чаще происходят дорожно-транспортные происшествия. Во многих странах мира страхование ответственности владельцев транспортных средств является обязательным.

С развитием обязательного страхования ответственности владельцев ТС также появилось и мошенничество в рамках этого вида страхования. В связи с этим многие государства предъявляют серьезные требования к работе страховых компаний, предоставляющих ОСАГО, а также следят за их работой. 
Во многих странах существует возможность оформить ДТП без участия полиции (при условии, что нет пострадавших) через европейский протокол. Благодаря этому намного упрощается процедура возмещения ущерба по ДТП и сокращается число судебных разбирательств при разногласиях сторонучастников происшествия. Такая практика также применяется и в Российской Федерации.

В большинстве стран мира величина страховых премий зависит от следующих факторов:

1) вид транспортного средства, его марка;

2) технические характеристики авто;

3) число, стаж и возраст лиц, управляющих транспортным средством;

4) территория эксплуатации;

5) характер использования автомобиля;

6) число ТС, подлежащих страхованию;

7) срок страхования.

Страховые тарифы ОСАГО регулируются государством.

На стоимость полиса ОСАГО может влиять коэффициент бонус-малус (КБМ). Он определяется для каждого водителя индивидуально и зависит от наличия или отсутствия страховых событий и возмещений, произошедших за определенный период [5, с. 198].

Существует два вида оформления страхового случая: с участием сотрудников полиции и без их участия. Дорожно-транспортное происшествие оформляется сотрудниками ГАИ в случае:

- если есть пострадавшие;

- если в аварии участвуют более двух транспортных средств;

- если кроме автомобилей получили повреждения объекты инфраструктуры (светофоры, фонарные столбы, здания и т.д.);

- если у одного или более водителей нет полиса ОСАГО.

Если данные события не произошли, то присутствие сотрудников ГИБДД не обязательно, достаточно оформления европротокола. Но многие водители даже при отсутствии этих событий предпочитают вызывать сотрудников ГАИ для того, чтобы они помогли водителям заполнить бланки европротокола, что не входит в обязанности правоохранителей. Для этого каждый страхователь обязан знать порядок оформления ДТП и правильность заполнения европейского протокола.

Европротокол (европейский протокол) - это более простой способ оформить документы о дорожно-транспортном происшествии, без участия сотрудников ГАИ. Другими словами, это возможность участниками аварии самостоятельно задокументировать факт ДТП для дальнейшего обращения в страховую компанию за получением страхового возмещения. Благодаря самостоятельному оформлению документов, участники ДТП не создают серьезных проблем и заторов на дороге [6, с. 36]. 
Европротокол действует во многих странах Евразии. В Российской Федерации европейский протокол появился в марте 2009 г. и действует на всей территории страны. В 2019 г. ДТП через европротокол оформили более 50 \% водителей.

Оформить ДТП по европротоколу можно только при соблюдении определенных условий (п. 1.6 ст.11.1 Закона от 25.04.2002 № 40-Ф3, ред. от 01.05.2019):

1. Не причинен вред жизни и здоровью лиц, участвовавших в ДТП.

2. ДТП произошло только с участием двух автомобилей, владельцы которых имеют полис ОСАГО.

3. Отсутствие разногласий у участников ДТП. Если разногласия все-таки имеются, необходимо техническое подтверждение (данные ГЛОНАСС, данные видеорегистратора и т.д.) [7, с. 62].

Оформить ДТП по европротоколу можно также в случае, если участник аварии управлял автомобилем, зарегистрированным в другой стране и имел страховой полис в рамках международных систем страхования (п. 1.1 ст. 11.1 Закона № 40-Ф3).

При оформлении ДТП через европротокол размер страхового возмещения, выплачиваемого потерпевшему за причинение вреда его автомобилю, в том числе при наличии разногласий, не должен превышать 100000 руб. (пп. «в» П. 1, П. 4 ст. 11.1 Закона №40-Ф3).

Страховое возмещение потерпевшему в пределах 400000 руб. осуществляется при условии отсутствия разногласий у водителей ТС, участвовавших в ДТП и при предоставлении страховщику данных о ДТП, зафиксированных установленными законом способами (пп. «б» ст.7, п. 6 ст. 11.1 Закона № 40-ФЗ).

Страховая компания выплачивает возмещение только на указанную сумму, даже если реальный ущерб намного больше.

Для оформления ДТП без сотрудников полиции необходимо следовать алгоритму:

1. Надо провести осмотр места и обстоятельства аварии совместно со вторым участником ДТП, а также определить степень механических повреждений и определить величину ущерба. Водители должны соблюдать меры предосторожности на проезжей части, оформляя документы. Находясь в ночное время суток вне населенных пунктов, водители должны быть одетыми в куртку или жилет с полосами светоотражающего материала (п. 2.3.4 Правил дорожного движения). Водители должны выяснить, есть ли у них разногласия, при отсутствии разногласий, а также если ущерб не превышает 100000 руб., необходимо зафиксировать обстоятельства причинения вреда транспортному средству.

2. Фиксация причинения ущерба чаще всего осуществляется с помощью фото- или видеосъемки. Фиксируется положение ТС по отношению друг к другу и ближайшим объектам инфраструктуры, предметы и следы, относя- 
щиеся к аварии, а также повреждения транспортных средств (п. 2.6.1 Правил дорожного движения).

3. Водителям-участникам дорожно-транспортного происшествия следует освободить проезжую часть, если это мешает проезду других транспортных средств (п. 2.6.1 Правил дорожного движения).

4. Необходимо проверить наличие действующего полиса ОСАГО, паспорта, водительских прав, техпаспорта.

5. Заполнение бланка извещения о ДТП (европротокола). Европротокол заполняется двумя водителями-участниками ДТП. Бланки извещения о ДТП выдаются страхователям непосредственно при заключении договора ОСАГО. Водители всегда должны иметь их при себе, во время управления ТС. В европротоколе указывается полная информация об автомобиле, всех его повреждениях, а также составляется схематический рисунок аварии. Также в бланке необходимо указать о пострадавших объектах, находящихся в автомобиле (ноутбук, детская коляска и т.п.) [8, с. 2].

При отсутствии полиса ОСАГО у виновного или потерпевшего, а также если есть сомнения по поводу обстоятельств аварии, неуверенность в определении виновника, сомнения относительно документов виновника или отсутствуют критерии, при которых ДТП оформляется без сотрудников полиции, необходимо вызвать сотрудников ГИБДД и оформить ДТП в общем порядке.

Обязательное страхование автогражданской ответственности в России закреплено в законе, а это значит, что для всех страховых компаний и для всех страхователей существуют одинаковые условия для страхования. Рассмотрим данную проблематику на примере АО «СОГАЗ», в связи с этим разберем автострахование в данной компании.

Страховая группа «СОГАЗ» была основана в 1993 г. и на сегодняшний день является крупнейшим страховщиком России на федеральном уровне.

АО «СОГАЗ» предлагает более 100 программ страхования, ориентированных на физических и юридических лиц разных областей деятельности.

Страховая компания «СОГАЗ» - это корпоративное юридическое лицо по законодательству РФ, коммерческая компания. Уставный капитал «СОГАЗ» составляют акции, подтверждающие права акционеров компании, созданной на неопределенный срок деятельности.

Место нахождения Пятигорского отделения Ставропольского филиала АО «СОГАЗ»: 357502, Ставропольский край, г. Пятигорск, пр. 40 лет Октября, 23.

Финансовая устойчивость, надежность и доверие компании подтверждено крупнейшими рейтинговыми агентствами международного уровня. Размеры страхового фонда, качественная защита страховых и перестраховочных рисков, а также собственный капитал организации делают ее самым надежным страховщиком Российской Федерации и гарантирует страхователям высочайший уровень предоставления страховых услуг и страховой защиты. 
$\mathrm{AO}$ «СОГАЗ» имеет более 800 филиалов, отделений и офисов продаж по всей стране, а также филиалы компании имеются в Республике Сербия и ФРГ. В будущем компания собирается выходить на Китайский страховой рынок.

Суммарные активы Страховой группы составляют более 250 млрд руб. Капитал компании составляет 80 млрд руб.

Страховая компания выплачивает страхователям возмещение по страховым случаям примерно 175 млн руб. в день.

На сегодняшний день в АО «СОГАЗ» застраховано более 85000 предприятий РФ, среди которых такие крупные предприятия, как «Газпром», РЖД, «Аэрофлот», «Роскосмос», «Роснефть», «Росатом», «Ростех», «Северсталь» и др., а также в компании застраховано более 20 млн чел. (каждый десятый страхователь) [9, с. 32].

В Страховой группе работают высококвалифицированные специалисты, обладающие уникальным опытом для рынка страхования, а также глубокими знаниями и технологиями страховой сферы. Компании Страховой группы входят в состав ведущих российских профсоюзов и объединений, а также принимают активное участие в развитии страхового рынка.

В компании используется линейно-функциональная структура управления, которая имеет следующие преимущества:

1) оперативность в принятии управленческих решений и приведение принятых решений в жизнь;

2) наличие относительной простоты при организации управленческих функций;

3) четко выраженная ответственность.

Данная структура также имеет свои недостатки:

- разобщенность горизонтальных связей в системах предприятия;

- способствует информационной перегрузке, так как имеет большое количество контактов с сотрудниками;

- увеличивается время принятия и реализации решений, так как решение происходит «сверху вниз»;

- имеется жесткая система, изменение которой невозможно.

Персонал Пятигорского отделения состоит из работников, принятых в соответствии с трудовым законодательством Российской Федерации. Трудовым кодексом РФ, а также нормативными документами АО «СОГАЗ» регулируются все вопросы, связанные с вопросами найма и увольнения, прав и обязанностей сотрудников, размера и формы заработной платы, формы поощрений и дисциплинарной ответственности, режим рабочего времени и времени отдыха и другие вопросы трудового характера.

Средний стаж штата Пятигорского отделения компании составляет от пяти до семи лет. Все сотрудники отделения имеют высшее образование. Весь штатный коллектив отделения женского пола. 
$\mathrm{AO}$ «СОГАЗ» уделяет большое внимание проблемам формирования и развития высокопрофессионального кадрового состава: первичному обучению, профессиональной переподготовке и повышению квалификации персонала.

В образовательный процесс обучения сотрудников АО «СОГАЗ» входят программы:

1) для всех новых сотрудников, не имеющих опыт работы, для ознакомления с компанией, ее политикой, миссией и принципами работы;

2) вводное обучение.

Важно выделить то, что в АО «СОГАЗ» ведется кадровая работа, которая направлена на усовершенствование качеств персонала. Наблюдается рост сотрудников с высшим образованием, сокращается текучесть кадров и оборота по приему. Все это является примером хорошей кадровой политики предприятия.

Молодые сотрудники, принятые в штат компании, не всегда соответствуют требованиям и опыту, необходимому для работы в страховой организации. Для их обучения и вливания в рабочий процесс созданы «Положения по адаптации новых сотрудников».

Можно сделать вывод, что АО «СОГАЗ» является страховщиком, находящимся на федеральном уровне, и крупнейшей страховой компанией России.

Автострахование в АО «СОГАЗ»- самый распространенный вид страхования. Компания предоставляет услуги по страхованию транспортных средств предприятий и физических лиц. Основные продукты автострахования - ОСАГО и «Автокаско».

ОСАГО покрывает финансовые убытки виновника страхового случая при следующих обстоятельствах:

- повреждение светофора или дорожного знака;

- въезд в здание или сооружение, его повреждение;

- повреждение других автомобилей-участников ДТП;

- въезд на пешехода, в результате чего ему был причинен вред жизни или здоровью.

Необходимые документы для получения полиса ОСАГО:

1) заявление на страхование;

2) паспорт гражданина РФ владельца авто;

3) СТС или ПТС;

4) действующее водительское удостоверение;

5) действующий техосмотр (диагностическая карта);

6) доверенность, если авто вам не принадлежит.

Стоимость полиса ОСАГО в СК «СОГАЗ» зависит:

- от категории и марки авто;

- возраста и пробега транспортного средства;

- мощности двигателя;

- водителя ТС (его возраста, стажа); 
- места проживания владельца автомобиля;

- истории страховых случаев по предыдущим полисам страхования.

Добровольное страхование автотранспорта («Автокаско») регулируется Правилами страхования средств транспорта и гражданской ответственности от 02.02.2003 г.

Для оформления договора страхования «Каско» необходимо предоставить страховщику следующие документы:

1) заявление на страхование;

2) паспорт или иное удостоверение личности;

3) регистрационные документы на ТС (паспорт ТС, свидетельство о регистрации ТС, справку-счет, договор купли-продажи, таможенные документы на ТС, и т.д.);

4) договор аренды (лизинга, залога) с правом страхования и получения страхового возмещения;

5) два комплекта ключей;

6) водительские удостоверения или их копии для всех лиц, допущенных к управлению ТС;

7) предыдущий полис страхования «Каско» (при наличии);

8) документы на противоугонные системы, установленные на ТС (при наличии);

9) ТС страховщику для осмотра, при этом страховщик не несет ответственности за повреждения ТС, имевшиеся на момент заключения договора «Каско» [10, с. 521].

На страхование в рамках «Каско» принимаются:

- легковые автомобили, произведенные за рубежом не позже 2010 г.;

- легковые отечественные автомобили, произведенные не позже 2010 г.

Расчет стоимости полиса «Каско» не является офертой, точный размер премии рассчитывается индивидуально для каждого автомобиля и зависит от возраста и стажа водителя, года выпуска транспортного средства, марки и модели авто, наличие сигнализаций, противоугонных систем, страховой франшизы.

По полису ОСАГО существует 2 сценария урегулирования убытков: с вызовом сотрудников ГИБДД или через европротокол.

Порядок действий при ДТП с вызовом ГИБДД:

1) виновнику и пострадавшему необходимо сообщить о страховом случае в колл-центр АО «СОГАЗ»;

2) необходимо сообщить другим участникам ДТП сведения о полисе ОСАГО, в том числе номер полиса ОСАГО, название страховой компании, адрес офиса и телефон;

3) следует вызвать сотрудников ГАИ;

4) все участники ДТП должны заполнить бланк европротокола, независимо от оформления извещения сотрудниками полиции; если нет возможности 
совместно заполнить один бланк, допускается заполнение отдельных бланков каждым водителем;

5) если авария произошла далеко от офиса страховщика, необходимо согласовать с АО «СОГАЗ» дальнейшие действия, зафиксировать на фотографиях поврежденное имущество и обратиться в уполномоченные экспертные и/или оценочные организации для осмотра поврежденного имущества и расчета ущерба;

6) необходимо подать заявления в офис СК «СОГАЗ»; заявление подаются в страховую компанию в течение пяти рабочих дней (не более). Если страховой случай произошел вдалеке от крупных населенных пунктов, то заявление можно подать в течение пятнадцати рабочих дней [11, с. 45$]$.

Если ущерб от дорожно-транспортного происшествия был нанесен имуществу, то для получения страховой выплаты необходимо предоставить следующие документы:

- документ, удостоверяющий личность, или его нотариально заверенная копия (в т.ч. доверенность на представителя);

- полис ОСАГО;

- заполненный бланк европротокола;

- документы на транспортное средство:

- ПТС;

- свидетельство о регистрации;

- если страховой случай наступил до момента государственной регистрации, документы, подтверждающие приобретение ТС (справка-счет, договор купли-продажи и др.);

- если страхователь (выгодоприобретатель) не является собственником, то действующий гражданско-правовой договор;

- копию кредитного договора с банком, если ТС приобретено в кредит;

- копию водительского удостоверения лица, управлявшего ТС в момент наступления события;

- заявление о страховой выплате;

- реквизиты банковского счета для перечисления страховой выплаты;

- документы, подтверждающие факт наступления страхового случая;

- заключение независимой экспертной организации и оригиналы документов, подтверждающих понесенные расходы, если потерпевший организовал экспертизу самостоятельно [12, с. 2].

После подачи заявления специалист компании отправляет запрос на экспертизу транспортного средства. После экспертизы компания виновника выплачивает возмещение компании пострадавшего. Компания пострадавшего, в свою очередь, выплачивает возмещение в натуральной или денежной форме.

В большинстве случаев приоритет принадлежит натуральной форме страхового возмещения. АО «СОГАЗ» вместо выплаты проводит ремонтные рабо- 
ты зарегистрированных на территории РФ легковых автомобилей на СТО, с которой «СОГАЗ» заключил договор. Новые автомобили, срок эксплуатации которых не достиг двух лет, отправляют на ремонт к официальному дилеру. На все виды работ, проведенных на СТО, предоставляется гарантия сроком до одного года.

Денежные выплаты пострадавшему владельцу транспортного средства осуществляются в следующих случаях:

- полная гибель авто, повреждения не подлежат ремонту;

- смерть пострадавшего;

- пострадавший страхователь, которому был нанесен тяжкий вред здоровью или вред средней тяжести, сам выбрал данный вид возмещения вместо ремонта ТC;

- стоимость ремонтных работ на СТО превышает лимит страхового возмещения;

- потерпевшим является инвалид, который при подаче заявления выбрал данный вид вместо ремонта ТС;

- СТО из списка партнеров компании не соответствует требованиям к организации восстановительного ремонта в отношении конкретного потерпевшего.

По любым вопросам можно обратиться непосредственно по телефону офиса АО «СОГАЗ», где был приобретен полис или круглосуточно по номеру горячей линии компании. Сотрудники «СОГАЗ» могут подробно объяснить и проконсультировать страхователей по вопросам урегулирования убытков.

Компания освобождается от выплаты страхового возмещения в связи со следующими обстоятельствами:

- ДТП наступило в результате стихийных бедствий или военных действий;

- в случаях, которые не являются страховыми (повреждения в ходе тестдрайва, во время обучения вождению, автогонок и др.);

- страхователь подал заявление на получение возмещения по истечении установленного срока в 5 рабочих дней;

- мошеннические действия, повлекшие преднамеренное наступление страхового случая;

- транспортное средство было отремонтировано до проведения осмотра страховщиком;

- если лицо, которое в момент ДТП управляло транспортным средством, не является законным владельцем ТС или не имеет доверенности;

- имеется поддельный страховой полис;

- отсутствие полиса ОСАГО на момент страхового случая;

- просрочен платеж по автострахованию, оформленный в рассрочку $[13$, с. 47$]$. 
Урегулирование убытков по «Каско» отличается от ОСАГО тем, что в любом случае потерпевшему страхователю будет выплачено возмещение в денежной форме. Виновник может обратиться для урегулирования убытка по гражданской ответственности только в том случае, если это прописано в договоре «Каско». Размер выплаты будет непосредственно таким, какой был прописан в договоре страхования по соглашению сторон.

Целью данной работы является изучение извещения о ДТП (европротокола), поэтому подробнее рассмотрим урегулирование убытков без участия сотрудников ГАИ.

Комплект европротокола состоит из двух одинаковых листов - лицевая сторона комплекта самокопирующаяся. Алгоритм оформления извещения о дорожно-транспортном происшествии состоит из следующих пунктов:

1. Водители заполняют одну из колонок извещения (один водитель - левую, другой - правую). Записываются общие данные ДТП, составляется схема происшествия:

- указываются улицы, их названия, а также находящиеся рядом объекты;

- обозначаются разметка дороги, знаки и светофоры;

- фиксируется расположение транспортных средств на момент столкновения;

- отмечаются направления движения автомобилей.

Затем листы бланка разъединяются, а водители ставят подписи непосредственно под своей колонкой в соответствующих графах нижней части формы. Всего водители ставят четыре подписи, по две в каждом бланке.

2. Далее водители по отдельности заполняют свою часть комплекта европротокола с другой стороны. Здесь происходит описание того, как произошла авария. Также отмечается:

- кто из водителей заполняет оборотную сторону данного листа («А» или «Б»)?

- кто управлял транспортным средством на момент ДТП - собственник или иное лицо?

- может ли машина двигаться самостоятельно? Если нет, то где она находится.

Затем участникам ДТП необходимо обратиться с заполненным извещением в свою страховую компанию в течение 5 дней.

Благодаря новым введениям ОСАГО стал более функциональным видом страхования, а процесс заключения договора и урегулирования убытков идет в ногу со временем, появляются электронные полисы, извещения от ДТП и т.д. Какой бы формы не было извещение о дорожно-транспортном происшествии, оно имеет единую структуру заполнения.

Для оформления дорожно-транспортного происшествия посредством извещения о ДТП необходимо знать структуру бланка, что и в каком месте поставить, подписать, а также каким образом описать страховой случай. 
Бланк европротокола имеет 2 стороны.

На первой стороне в обязательном порядке указывается:

- место ДТП;

- дата и время ДТП;

- количество транспортных средств, участвовавших в ДТП;

- имеются ли лица, получившие телесные повреждения;

- имеется ли материальный вред (повреждения ТС и иных объектов);

- имеются ли свидетели дорожно-транспортного происшествия $[14$, с. 68$]$.

Далее бланк делится на 2 столбца («Транспортное средство «А»» и «Транспортное средство «В»»), каждый из которых заполняется одним из водителей. Эти столбцы содержат информацию об участниках ДТП:

- информация о страхователе (ФИО или наименование юридического лица, адрес, индекс, телефон или е-mail);

- информация о транспортном средстве (марка, модель, регистрационный знак и страна регистрации транспортного средства);

- информация о страховщике (наименование, серия и номер страхового свидетельства, страна, телефон или е-mail);

- информация о водителе (ФИО, дата рождения, адрес, телефон или e-mail, водительское удостоверение, категория);

- место первоначального удара ТС (указывается на схеме);

- описание видимых повреждений транспортного средства и иного поврежденного имущества;

- примечания;

- пункт, в котором указывается, кто несет ответственность за причинение вреда (кто является виновником);

- имеются ли разногласия между водителями;

- подпись водителей.

Между этими столбцами расположен пункт «Обстоятельства ДТП», в котором участники ДТП отмечают нужные подпункты, связанные с аварией.

На второй стороне водители подробно в виде текста описывают свои версии обстоятельств ДТП, информация о поврежденном имуществе помимо транспортных средств, может ли ТС передвигаться своим ходом, примечания, дата и подпись.

Вся информация должна быть согласована между водителями, если имеются исправления, они должны быть заверены подписями обоих водителей. Не должно быть противоречий в обстоятельствах, указанных каждым водителем. Bce пустые графы должны быть заполнены прочерком или буквой Z, незаполненных граф быть не должно.

Подписи участников ДТП обязательны, без них извещение о дорожнотранспортном происшествии считается недействительным. 
После заполнения бланка извещения участникам необходимо еще раз проверить правильность заполнения бланка и истинность указанных в нем фактов. Если есть ошибки, исправить их, заверив подписью обоих водителей. Если водители уверены, что европротокол заполнен правильно, то в течение 5 рабочих дней они должны предоставить бланки своим страховщикам.

Различные ошибки, допущенные при заполнении европротокола, могут иметь неприятные для страхователя последствия.

При незначительных ДТП водители испытывают опасения, так как установленного лимита страхового возмещения может не хватать на полноценный и качественный ремонт транспортного средства. Даже самые небольшие ошибки и неточности при заполнении бланка европротокола могут стать причиной того, что страховщик откажет в возмещении ущерба по ОСАГО.

Так или иначе европротокол имеет определенные преимущества:

1. Быстрота оформления дорожно-транспортного происшествия. ДТП оформляется без сотрудников ГАИ. Это самое большое преимущество европротокола. Заполнение бланка протокола и фиксация ДТП с помощью фотосъемки занимает не больше 15 минут, в то время как ожидание и работа сотрудников полиции может занимать несколько часов.

2. Финансовое послабление виновнику. Виновник ДТП привлекается к административной ответственности (штраф) при вызове сотрудников ГАИ, а при оформлении ДТП через европротокол он не несет административной ответственности.

Помимо преимуществ оформление европейского протокола - довольно рискованное дело [15, с. 52].

Среди недостатков и рисков оформления ДТП через европротокол можно выделить следующие:

1. Стрессовая ситуация. Стресс, разногласия и недопонимания участников аварии, упущение важных деталей ДТП может привести к неправильному заполнению бланка и (или) привести к тому, что вина перейдет на пострадавшего водителя.

2. Из-за строгих правил распространить действие европротокола можно только на мелкие аварии, без пострадавших и серьезных повреждений имущества.

3. При неадекватной оценке ущерба и превышении установленного размера пострадавший может потребовать у виновного возврата разницы, недополученной от страховщика.

4. Документы имеются в единственном экземпляре, поэтому невозможно получить их копии. При возникновении спорных ситуаций эти документы можно получить только по запросу суда.

5. Страховая компания может отказать в выплате, если в бланке протокола будут иметься недостоверные данные о водителях, транспортных средствах, событиях дорожно-транспортного происшествия. 
Оформление незначительного дорожно-транспортного происшествия через европротокол является обязанностью всех участников аварии. В таких случаях нет необходимости вызывать сотрудников ГИБДД. Но, несмотря на это, если имеются какие-либо сомнения в размере ущерба, обстоятельствах аварии или трезвости водителей, лучше вызвать сотрудников ГАИ и оформить ДТП по классической схеме [16, с. 56].

Водители транспортных средств редко самостоятельно оформляют ДТП через европротокол, без участия органов полиции. Это связано с тем, что страхователи не понимают, в каких случаях можно воспользоваться европротоколом $[17$, с. 82$]$. Людям легче вызвать сотрудников компетентных органов для оформления дорожно-транспортного происшествия, чем заполнить небольшой бланк европейского протокола, несмотря на то, что оформление с помощью ГАИ занимает намного больше времени.

Часты случаи, когда участники ДТП заполняют европротокол, но при этом вызывают сотрудников ГИБДД, тем самым отвлекая их от работы. Для этого сотрудники страховых компаний должны подробно разъяснять страхователям о сущности европротокола, порядке действий при ДТП, объяснять, когда нужно, а когда не нужно вызывать сотрудников полиции.

Страховые компании также должны выпускать специализированные брошюры, информирующие о том, как действовать при ДТП, как правильно заполнять бланк. Такая информация также должна находиться на сайте компании в доступном пользователю месте. Если страховщики позаботятся о просвещении страхователей о функциях европейского протокола, то страхователи будут в разы меньше отвлекать сотрудников полиции от действительно важной работы.

Многие водители пребывают в стрессе из-за случившейся аварии, поэтому совершают ошибки при оформлении европротокола. Ошибки могут также совершаться при первичном заполнении бланка. Самыми распространенными недочетами при заполнении бланка европейского протокола являются:

- отсутствие отметки об общем количестве заполненных полей (клеток) в П. 16 лицевой стороны бланка (обстоятельства ДТП);

- незаполнение п. 16 лицевой стороны бланка;

- неполный перечень внешних повреждений авто;

- отсутствие подписей, подтверждающих согласие участников с указанной информацией (п. 18 лицевой стороны) [18, с. 189].

Кроме этого, имеются также некоторые нормативные особенности, затрудняющие использование извещения о дорожно-транспортном происшествии. К ним можно отнести:

1. Отсутствие четко регламентированного указания на виновность одной из сторон. На практике страховщики часто требуют соответствующую отметку от виновника в «Замечаниях» на лицевой стороне бланка или в «Обстоятельст- 
вах ДТП» (иногда в «Примечаниях») на оборотной. Хотя формально подобные требования ничем не подкреплены. Данная ситуация влечет возможные злоупотребления как со стороны виновника ДТП, так и со стороны страховых компаний.

2. При урегулировании убытков через европротокол потерпевший не имеет права требовать от страховщика дополнительного возмещения имущественного вреда после получения страховой выплаты. Законодательно не оговаривается, относится ли это только к «неучтенным» первоначально повреждениям или позиция фактически запрещает оспаривать размер возмещения. Наличие подобного «подводного камня» закономерно настораживает автолюбителей [19, с. 89].

Система оформления дорожно-транспортного происшествия через европротокол распространена почти во всех странах Евразии, что автоматически доказывает то, что она удобна и совершенна. В России же водители к ней пока привыкают, хотя ДТП с вызовом полиции становятся все реже и реже. Так или иначе, оформление дорожно-транспортного происшествия через европротокол производится проще и намного быстрее, чем оформление с помощью сотрудников полиции, хоть и имеет свои нюансы и недостатки.

С увеличением автомобильного движения увеличивается и потребность в приобретении водителями полиса ОСАГО. Этот вид страхования обязателен для всех владельцев транспортных средств.

Одним из сценариев урегулирования убытков по ОСАГО является оформление дорожно-транспортного происшествия через европротокол, без участия сотрудников ГАИ. Это значительно облегчает процесс оформления ДТП, экономит время участников происшествия и не создает затора на дорогах. Но многие страхователи ввиду стрессовых ситуаций и (или) по незнанию все равно вызывают сотрудников полиции для помощи в оформлении извещения о ДТП.

В ходе исследования выяснилось, что для понимания страхователями сущности оформления дорожно-транспортного происшествия через европротокол сотрудники страховых компаний должны подробно разъяснять страхователям о сущности европротокола, порядке действий при ДТП, объяснять, когда нужно, а когда не нужно вызывать сотрудников полиции, печатать информационные буклеты и брошюры, содержащие алгоритм действий при ДТП и заполнении извещения о ДТП.

Помимо преимуществ европейский протокол имеет некоторые недостатки:

1) при допущении ошибки в бланке извещения могут быть неприятные последствия (вина может перейти на пострадавшего или из-за ошибки страховщик может отказать в выплате);

2) европротокол действует только при незначительных ДТП, в остальных случаях необходимо оформлять ДТП с участием сотрудников ГАИ; 
3) документы имеются в единственном экземпляре, поэтому невозможно получить их копии. При возникновении спорных ситуаций эти документы можно получить только по запросу суда.

В страховой компании «СОГАЗ» автострахование - это один из популярных видов страхования. За день в отдел по урегулированию убытков по автострахованию в Пятигорское отделение компании приходит около 7 человек, и в основном они приходят с оформленными бланками европротокола. Сотрудники компании всегда готовы помочь с любыми вопросами, связанными с оформлением дорожно-транспортного происшествия и урегулированием убытков с помощью европейского протокола [20, с. 141].

Европротокол - очень полезная вещь по своей задумке. Но недостаточная степень его нормативной проработки, к сожалению, не позволяет популяризировать схему. Кроме того, практика его применения вводит свои коррективы. В связи с этим самостоятельное оформление дорожно-транспортного происшествия во многом связано с определенными рисками. Сложность системы и недостаточная осведомленность об этом инструменте становится причиной многих ошибок, которые совершают страхователи, оформляя дорожнотранспортное происшествие. Из-за этих ошибок могут возникнуть проблемы с выплатой страхового возмещения по полису обязательного страхования автогражданской ответственности.

В то же время доля отказов в возмещении ущерба по европротоколу из-за ошибок в оформлении колеблется в пределах 1-5\% от общего числа обращений, а значит, в подавляющем большинстве случаев участники ДТП вполне справляются с задачей.

Система европейского протокола в России продолжает совершенствоваться и можно быть уверенным в том, что в будущем именно благодаря ей, процесс урегулирования убытков станет еще проще и быстрей.

\section{Список литературы}

1. Бабурина Н.А. Страховое дело. Страховой рынок России. - М.: Юрайт, 2019. -128 c.

2. Акофф Р. Планирование будущего корпорации. - М.: Прогресс, 2018. $328 \mathrm{c}$.

3. Гвозденко С.Н. Страхование. - М.: ТК Велби: Проспект, 2016. - 464 с.

4. Сафуанов В.А., Шарифьянова 3.Ф. Страхование: учеб. пособие. - М.: Прометей, 2018. - 144 с.

5. Астратова Г.В. Особенности возникновения и развития страхования в России. - СПб.: Мысль 2017. - 434 с.

6. Аренков И.А. Маркетинг-менеджмент на крупных российских предприятиях. - СПб: СПб Известия, 2017. - 355 с. 
7. Стадии жизненного цикла продукта [Электронный ресурс]. - URL: http://powerbranding.ru/marketing-strategy/razvitiye-tovara (дата обращения: 11.03.20120).

8. Хоминич И.П. Страхование. - СПб.: Прогресс, 2018. - 224 с.

9. Браверман А.А. Страхование в российской экономике переходного периода: Методология и практика. - М.: Экономика, 2017. - 637 с.

10. Чернова Е.Г. Страхование и управление рисками. - М.: Юрайт, 2018. $-768 \mathrm{c}$.

11. Функции страхования [Электронный ресурс]. - URL: http://ecsocman.hse.ru/text/19171755/ (дата обращения: 24.05.2020).

12. Балабанова Л.В. Оптовая торговля. - М.: Экономика, 2018. -207 с.

13. Пономарева Т.Н. Страхование. - СПб.: Прогресс, 2018. - 321 с.

14. Багиев Г.Л. Страхование: Информационное обеспечение, диагностика. - СПб.: Изд-во СПбГУЭФ, 2017. - 140 с.

15. Ермасов С.В. Страхование: в 2 ч. - СПб.: Правда, 2019. -475 с.

16. Аунапу Ф.Ф. Научные методы принятия решений в управлении производством. - М.: Экономика, 2017. - 134 с.

17. Азоев Г.Л. Конкуренция: анализ, стратегия и практика. - М.: Центр экономики и маркетинга, 2017. - 208 с.

18. Венделин А.Г. Подготовка и принятие управленческого решения: Методологический аспект. - М.: Экономика, 2017. - 150 с.

19. Багиев Г.Л. Страхование в системе управления предпринимательством. - Подольск, 2016. -231 с.

20. Шарифьянова З.Ф. Страхование: Информационное обеспечение, диагностика. - СПб.: Изд-во СПбГУЭФ, 2018. - 180 с.

\section{References}

1. Baburina N.A. Strakhovoe delo. Strakhovoi rynok Rossii [Insurance business. Insurance market of Russia]. Moscow, Iurait, 2019, 128 p.

2. Akoff R. Planirovanie budushchego korporatsii [Planning of corporation future]. Moscow, Progress, 2018, 328 p.

3. Gvozdenko S.N. Strakhovanie [Insurance]. Moscow, TK Velbi, Prospekt, 2016, 464 p.

4. Safuanov V.A., Sharifianova Z.F. Strakhovanie [Insurance]. Moscow, Prometei, 2018, $144 \mathrm{p}$.

5. Astratova G.V. Osobennosti vozniknoveniia i razvitiia strakhovaniia v Rossii [Origin and development of insurance in Russia]. St. Petersburg, Mysl', 2017, $434 \mathrm{p}$.

6. Arenkov I.A. Marketing-menedzhment na krupnykh rossiiskikh predpriiatiiakh [Marketing management at large Russian enterprises]. St. Petersburg, SPb Izvestiia, 2017, $355 \mathrm{p}$. 
7. Stadii zhiznennogo tsikla produkta [Stages of product lifecycle]. Available at: http://powerbranding.ru/marketing-strategy/razvitiye-tovara (accessed 11.03.2020).

8. Khominich I.P. Strakhovanie [Insurance]. St. Petersburg, Progress, 2018, $224 \mathrm{p}$.

9. Braverman A.A. Strakhovanie $\mathrm{v}$ rossiiskoi ekonomike perekhodnogo perioda: Metodologiia i praktika [Insurance in Russian transition economy: Methodology and practice]. Moscow, Ekonomika, 2017, 637 p.

10. Chernova E.G. Strakhovanie i upravlenie riskami [Insurance and risk management]. Moscow, Iurait, 2018, 768 p.

11. Funktsii strakhovaniia [Insurance options]. Available at: http://ecsocman. hse.ru/text/19171755/ (accessed 24 May 2020).

12. Balabanova L.V. Optovaia torgovlia [Wholesale]. Moscow, Ekonomika, 2018, 207 p.

13. Ponomareva T.N. Strakhovanie [Insurance]. St. Petersburg, Progress, 2018, $321 \mathrm{p}$.

14. Bagiev G.L. Strakhovanie: Informatsionnoe obespechenie, diagnostika [Insurance: Information support, diagnostics]. St. Petersburg, Saint Petersburg University of Economics, 2017, $140 \mathrm{p}$.

15. Ermasov S.V. Strakhovanie: v 2 ch. [Insurance. In 2 parts]. St. Petersburg, Pravda, 2019, $475 \mathrm{p}$.

16. Aunapu F.F. Nauchnye metody priniatiia reshenii $\mathrm{v}$ upravlenii proizvodstvom [Scientific decision-making methods in production management]. Moscow, Ekonomika, 2017, 134 p.

17. Azoev G.L. Konkurentsiia: analiz, strategiia i praktika [Competition: Analysis, strategy and practice]. Moscow, Economics and Marketing Centre, 2017, $208 \mathrm{p}$.

18. Vendelin A.G. Podgotovka i priniatie upravlencheskogo resheniia: Metodologicheskii aspekt [Preparation and adoption of management decisions: Methodological aspect]. Moscow, Ekonomika, 2017, 150 p.

19. Bagiev G.L. Strakhovanie v sisteme upravleniia predprinimatel'stvom [Insurance in the business management system]. Podolsk, 2016, $231 \mathrm{p}$.

20. Sharifianova Z.F. Strakhovanie: Informatsionnoe obespechenie, diagnostika [Insurance: Information support, diagnostics]. St. Petersburg, Saint Petersburg University of Economics, 2018, 180 p.

Оригинальность $87 \%$

Получено 24.06.2020 $\quad$ Принято 20.07.2020 Опубликовано 28.12.2020 


\section{G.E. Kontsevich}

\section{SETTLING DAMAGES THROUGH THE EUROPEAN ACCIDENT STATEMENT}

One of the most common types of insurance is car insurance. This is due to the fact that the number of cars on the roads is rapidly increasing every day, and therefore there is a greater chance of getting into a traffic accident.

In the Russian Federation, there are 2 types of car insurance: voluntary and compulsory motor third party liability insurance. According to the law, each vehicle owner must have a compulsory motor liability insurance policy.

Losses can be compensated both with the participation of traffic police officers and without them through the European Accident Statement. In the SOGAZ insurance company, losses are most often regulated through the European Accident Statement. Today, all minor accidents are registered only through a traffic accident notification, but not all policyholders have a complete understanding of the European Accident Statement and often make mistakes.

The European Accident Statement has long been used in most countries of the world, which makes it convenient when traveling by car abroad (provided that there is a "Green Card").

The purpose of the study is to reveal the essence of a traffic accident notice (the European Accident Statement) and the settlement of road accident losses through this protocol.

The European Accident Statement is a very useful thing in its concept. But its insufficient legal base, unfortunately, does not allow to popularize the procedure. In addition, the practice of its application introduces its own adjustments. In this regard, the self-registration of a traffic accident is largely associated with certain risks. The complexity of the system and the lack of awareness of this tool is the reason for many mistakes made by policyholders in registering a traffic accident. Due to these errors, problems may arise with insurance compensation under the compulsory motor third party liability insurance policy.

At the same time, the share of refusals to compensate for damages because of incorrect registration by the European Accident Statement is one to five percent of the total number of requests. So, in the vast majority of cases, road accident participants are rather capable of coping with the task.

The system of the European Accident Statement in Russia continues to improve and one can be sure that in future it will definitely ease the process of compensating the losses.

Keywords: Iosses, European Accident Statement, insurance, participants, compensation, car, accident, car insurance, liability, market relations.

Galina E. Kontsevich - Candidate of Sociological Sciences, Associate Professor, Department of Humanities and Socio-Economic Disciplines, Zheleznovodsk Branch of the Stavropol State Pedagogical Institute, e-mail: galinakoncevich@rambler.ru.

Received 24.06.2020 $\quad$ Accepted 20.07.2020 Published 28.12.2020 